\title{
The Dimensions of Wage Inequality among Aboriginal Peoples
}

\author{
by Rachel Bernier
}

No. 109

\author{
11F0019MPE No. 109 \\ ISSN: 1200-5223 \\ ISBN: 0-0660-17269-0
}

Price: $\$ 5.00$ per issue, $\$ 25.00$ annually

Business and Labour Market Analysis

24, R.H. Coats Building, Ottawa, K1A 0T6

Facsimile Number: (613)951-5403

\section{December 1997}

I wish to thank Harvey Lazar (Queen's University), René Morissette (Statistics Canada), Norbert Robitaille (Université de Montréal) and Dominique Collin (Department of Indian and Northern Affairs) for having shared their opinions on this topic with me. While I learned much from them, the views expressed in this paper are my own.

This paper represents the views of the author and does not necessarily reflect the opinions of Statistics Canada. 
Table of Contents

I- Introduction — 1

II- Review of Earlier Studies ___ 1

III- Wage Dispersion Between Aboriginal and Canadian Workers __ 3

$I V$ - Comparison of mean earnings between Aboriginal groups ___ 11

V- Wage inequality within Aboriginal communities___ 13

VI- Conclusion _ 15

References__ 16

Appendix 1: Concepts, definitions and data sources __ 18

Appendix 2: Tables _ 23 


\section{Abstract}

In addition to confirming a wage gap between Canadian workers as a whole and those of Aboriginal origin, our research also generated new findings: there is greater disparity in the distribution of wages among Aboriginals than among Canadian workers as a whole, even after allowing for demographic differences.

Our analysis does not stop there. Indeed, this analysis can hide considerable wage dispersions between Aboriginal groups since appreciable wage gaps were noted between these groups. Having said this, wage dispersion is most likely greater for certain Aboriginal groups than others. Since this aspect has never been studied before, the purpose of this paper is to document differences in wage dispersion for the four main Aboriginal groups. Our results show that North American Indians living on reserves are the most disadvantaged Aboriginal group because their earnings are substantially lower than those of the other groups.

Key words: Inequality, Polarization, Aboriginals 



\section{I- Introduction}

Over the past decade there has been increased interest in the issue of wage inequality. This growing interest is attributable to the fact that the gap between the highest and lowest paid workers in the United States, Canada and several other OECD countries widened during the 1980s (Beach and Slotsve, 1996; Morissette, 1995; OECD, 1993). This increase in wage inequality placed added pressure on the government transfer system at a time of budget cutbacks and weak economic growth. In Canada, most research in recent years has involved a study of Canadian wage dispersion. The first purpose of this paper is to examine wage dispersion between two specific groups: Canadian workers as a whole and workers of Aboriginal origin.

A number of studies have looked at the mean earnings of Aboriginal peoples and Canadian workers (George et al., 1994; George and Kuhn, 1994; Pendakur and Pendakur, 1996). All of these studies show that there is a significant wage gap between these two groups, even allowing for differences in personal characteristics. Another study (Clatworthy et al., 1995) examined wage gaps between Aboriginal groups. Workers of Aboriginal origin are a very heterogeneous group. Some live on reserves or in remote areas, while others live in urban settings. Each major Aboriginal peoples (North America Indians living on reserve, North American Indians living off reserve, Métis and Inuit) has its own culture. There are also considerable differences from one band to another. To date, no study has compared the wage dispersion between the various Aboriginal groups. The second purpose of this paper is to examine this issue. It is an important issue since a relatively unequal distribution of wages for a given group may create greater social problems than a more equal distribution (Beach and Slotsve, 1996).

Our findings confirm the wage gap between Canadian workers as a whole and those of Aboriginal origin, to the detriment of the latter group. Our research also generated new findings: there is greater disparity in the distribution of wages among Aboriginals than among Canadian workers as a whole, even after allowing for demographic differences.

This paper is organized as follows: we begin with a brief review of earlier studies relating to the Aboriginal issue (Section II). We then show that the wage dispersion is greater among workers of Aboriginal origin than among Canadian workers as a whole (Section III). This analysis can hide the fact that there is substantial wage disparity between Aboriginal groups, since our analysis in Section IV reveals appreciable wage gaps between these groups. Section V contains our findings of greater wage dispersion for certain Aboriginal groups. Section VI presents the conclusions of this study.

\section{II- Review of Earlier Studies}

As there are not many sources of data on Aboriginal peoples, virtually all of the studies use Statistics Canada data from the 1991 Census Public Use Microdata File (PUMF) (George et al., 1994; Pendakur and Pendakur, 1996), except for Clatworthy et al. (1995) which uses the postcensal 1991 Aboriginal Peoples Survey (APS) as well as the 1991 Census data. The first two studies are based on the concept of Aboriginal origins, that is, an Aboriginal is any Canadian who reported Aboriginal origins on the Census. Clatworthy et al. (1995) however use the more restrictive concept of Aboriginal identity, where to be considered Aboriginal, a Canadian must have reported Aboriginal origins on the Census and have identified him/herself with one of the major Aboriginal peoples in the postcensal APS. Below is a thematic review of these studies: 


\section{- Employment rate}

George et al. (1994) found that, in 1990, the employment rate ${ }^{1}$ of Canadians of non-Aboriginal origins was $70.4 \%$, or $11.7 \%$ higher than the employment rate of Aboriginals which was at only $58.7 \%$.

\section{- Wage gaps between Canadians and Aboriginal peoples}

After allowing for personal characteristics, George and Kuhn (1994) found a wage gap of $11 \%$ between Canadian workers and workers of Aboriginal origin ${ }^{2}$ (full-time full-year workers), which the authors considered to be relatively small compared to the wage gap between men and women which is around 35\%. Their findings show that like the black-white wage gap in the United States, the Aboriginal-Non-Aboriginal gap in Canada is considerably smaller for women than for men. Moreover, the wage gap is wider for persons reporting exclusively Aboriginal origins than for those with mixed origins. Workers of Aboriginal origin only can probably be compared to our study when we consider Aboriginals who identify themselves with one of the Aboriginal peoples.

Pendakur and Pendakur (1996) note that Aboriginal workers earn less than white workers or workers of visible minorities born in Canada. For example, they found that Aboriginal men earn a wage that is $11 \%$ lower than white workers, while workers of visible minorities earn $8 \%$ less than white workers. George et al. (1994) obtained similar results, concluding that Aboriginal Canadians working full-time full-year earn less than their non-Aboriginal Canadian colleagues doing the same job.

\section{- Explanation of wage gaps between Canadian and Aboriginal workers}

Using the 1986 Census data, George and Kuhn (1994) determine that a significant portion (approximately 50\%) of the wage gap between workers of Aboriginal origin only and non-Aboriginal workers can be "explained" by differences in their respective observable characteristics, primarily education.

\section{- Wage gaps between Aboriginal groups}

Clatworthy et al. (1995) is the only study to look at the issue of wage gaps between Aboriginal groups. They subdivide Aboriginals into four groups: registered Indian, non-registered Indians, Métis and Inuit. Mean employment income for 1990 is around \$17,367 for workers of Aboriginal origin as a whole although there are considerable variations between the four groups. Clatworthy et al. found that employment income was substantially higher for non-registered Indians $(\$ 21,035)$ and Métis $(\$ 18,467)$ than for registered Indians $(\$ 15,791)$ and Inuit $(\$ 15,690)$. Among workers who worked for most of 1990 (40 or more weeks), the wage gap tends to be smaller. Nevertheless, the authors conclude that the wages of registered Indians fall far behind those of other Aboriginal groups.

1 The employment rate represents the number of persons employed expressed as a $\%$ of the population 15 years of age and over.

2 Workers living off-reserve and outside the Yukon and Northwest Territories.

Analytical Studies Branch - Research Paper Series

Statistics Canada No. 11F0019MPE No. 109 


\section{- Wage dispersion}

While there have been a number of studies on wage dispersion in Canada, to date none has focused on the issue of wage dispersion among Aboriginal workers. No study has looked at the wage dispersion between Aboriginal workers and Canadian workers as a whole, nor between Aboriginal groups.

\section{III- Wage Dispersion Between Aboriginal and Canadian Workers}

The study of wage dispersion ${ }^{3}$ among Aboriginal peoples is an important aspect of the Canadian economy for reasons of equity and social cohesion, among others. We have taken two main approaches, which have been used in studies examining earnings inequality and polarization on a national scale and have applied them to the study of Aboriginal peoples. The type of measures used namely, the Gini coefficient, the exponential measurement and the coefficient of variation for inequality and the FWP polarization measure - come from these studies. ${ }^{4}$ (Beach and Slotsve, 1996; Morissette, 1994a, 1994b, 1995, 1996; Wolfson, 1995)

The first step in studying the wage dispersion among Aboriginal workers was to verify whether Aboriginal workers are over-represented at the bottom of the wage distribution and under-represented at the top end compared to Canadian workers as a whole. We began by looking at the wage gap between Aboriginal workers and Canadian workers as a whole. ${ }^{5}$ These results, combined with the various measures of inequality and polarization, enable us to determine whether the wage distribution of Aboriginal peoples is more or less equal than that of Canadians as a whole.

\section{- The earnings of Aboriginal workers are lower than Canadian workers as a whole}

Canadian workers reporting Aboriginal origins earned \$6,500 less than Canadian workers as a whole in 1991 (Table 1). For those who identified in 1991 with one of the Aboriginal peoples, their earnings were a further $\$ 2,900$ lower (which means they earned $\$ 9,400$ less than Canadian workers as a whole). Although the Aboriginal population is less educated, the wage gap may also be attributable to the fact that Aboriginal workers (aged 18 to 64 years) are on average, three years younger than the Canadian labour force as a whole (aged 18 to 64 years). ${ }^{6}$

3 We regularly use the terms "wage" and "earnings" to refer to "wages and salaries".

4 See Appendix 1 for details on these measures.

5 Our study targets workers between the ages of 18 and 64 years who received earnings in 1990. Refer to Appendix 1 for more details on definitions and data sources.

6 Clearly, the analysis also has to take into consideration the fact that Aboriginals living on-reserve do not pay income tax. For example, an Aboriginal with a taxable income of $\$ 20,000$ can save about $\$ 4,000$ in income tax depending on the province of residence and the taxation year. Accordingly, two people with the same demographic and socio-economic characteristics, one of whom is a registered Indian living on reserve and the other is living off reserve (he may or may not be an Aboriginal), will not have the same disposable income for the same earnings. The Indian living on reserve requires only $\$ 16,000$ in earnings to match his counterpart living off reserve with earnings of $\$ 20,000$. Indian band communities also play an important role and can certainly raise the standard of living - compared to the rest of the Canadian population - for the same level of income.

Analytical Studies Branch - Research Paper Series

$-3-$

Statistics Canada No. 11F0019MPE No. 109 
Table 1: Mean income by source for Canadian workers as a whole by Aboriginal origin, 1991

\begin{tabular}{|lccc||}
\hline \hline $1995 \$)$ & Canadians & $\begin{array}{c}\text { Aboriginal } \\
\text { origins }\end{array}$ & $\begin{array}{c}\text { Aboriginal } \\
\text { identity }\end{array}$ \\
\hline Wages and salaries & $\$ 27,700$ & $\$ 21,200$ & $\$ 18,300$ \\
Income from self-employment & $\$ 400$ & $\$ 250$ & $\$ 150$ \\
Investment income & $\$ 900$ & $\$ 250$ & $\$ 100$ \\
Pensions and annuities & $\$ 200$ & $\$ 100$ & $\$ 100$ \\
Other cash income & $\$ 200$ & $\$ 150$ & $\$ 150$ \\
& & & \\
Family allowances & $\$ 200$ & $\$ 250$ & $\$ 350$ \\
Fed. child tax credit & $\$ 150$ & $\$ 250$ & - \\
Old age security & - & - & $\$ 400$ \\
CPP/QPP & $\$ 70$ & $\$ 40$ & $\$ 1,000$ \\
Unemployment insurance benefits & $\$ 800$ & $\$ 1,000$ & $\$ 700$ \\
Other government transfer payments & $\$ 200$ & $\$ 500$ & $\mathbf{\$ 2 , 5 0 0}$ \\
Sub-total: Government transfers & $\mathbf{\$ 1 , 4 0 0}$ & $\mathbf{\$ 2 , 0 0 0}$ & $\mathbf{\$ 2 1 , 3 0 0}$ \\
\hline TOTAL INCOME & & & $\mathbf{\$ 2 4 , 0 0 0}$ \\
\hline \hline
\end{tabular}

Sources: Statistics Canada, 1991 Census (PUMF) and Aboriginal Peoples Survey, 1991, (adults file)

\section{- Greater inequality and polarization of wage distribution among Aboriginal workers than Canadian workers as a whole}

All of the measures of inequality and polarization show that there is greater inequality and polarization of wage distribution among Canadians reporting Aboriginal origins than among Canadian workers as a whole (Table 2). ${ }^{7,8}$ This greater disparity may be attributable to demographic differences between the two groups. For example, the portion of young workers aged 18 to 24 is higher for Aboriginal peoples $(23 \%)$ than for Canadian workers as a whole $(17 \%)$. Since wage dispersion is normally higher for young workers than older workers, this may explain part of the gap.

7 For example, the FWP index shows a higher level of polarization among Canadians with Aboriginal origins ( $F W P=0.261$ ) compared to Canadians as a whole ( $F W P=0.210$ ). The FWP index is even higher when Aboriginal status is restricted to those who identified as Aboriginal ( $\mathrm{FWP}=0.303$ ).

8 The more restrictive the definition of Aboriginal, the greater the inequality and polarization of their wage distribution. We noted that the wage distribution was more unequal and more polarized for Canadians with Aboriginal origins than for the population as a whole; and Canadians who identified as one of the Aboriginal peoples (in 1991) had an even more unequal and polarized wage distribution than the group of Canadians who simply reported Aboriginal origins. (Refer to Table A1 in the Appendix for the inequality and polarization measures.) 
Table 2: Inequality and polarization measures for wage distribution for Canadian workers

as a whole by Aboriginal origin, 1991

Wage dispersion is greater for Aboriginal workers

than for Canadian workers as a whole

\begin{tabular}{|c|c|c|c|c|}
\hline & \multicolumn{3}{|c|}{ Inequality measures } & \multirow{2}{*}{$\begin{array}{c}\begin{array}{c}\text { Index of } \\
\text { polarization }\end{array} \\
\text { FWP }\end{array}$} \\
\hline & Gini & Exp. & $\mathrm{CV}$ & \\
\hline All Canadians & $0.407^{9}$ & 0.463 & 0.634 & 0.210 \\
\hline Men & 0.373 & 0.450 & 0.534 & 0.177 \\
\hline Women & 0.408 & 0.463 & 0.597 & 0.221 \\
\hline Canadian with Aboriginal origins & 0.451 & 0.482 & 0.750 & 0.261 \\
\hline Men & 0.431 & 0.474 & 0.671 & 0.237 \\
\hline Women & 0.450 & 0.482 & 0.726 & 0.273 \\
\hline
\end{tabular}

Sources: Statistics Canada, 1991 Census (PUMF)

\section{- The wage dispersion is greater for women than for men}

Just as the literature shows a greater wage dispersion for Canadian women than for men, we also noted the same phenomenon among Aboriginal peoples.

\section{- Aboriginals have a different socio-economic profile}

Aboriginal peoples also have less education than Canadians as a whole (see Table A1 appended). Thirty-five per cent of Aboriginal workers aged 18 to 64 have only elementary or secondary schooling without a graduation diploma, compared to $25 \%$ for Canadians as a whole. Part of the gap may be explained by the fact that we have found that the dispersion is higher among less-educated Aboriginal workers than among those with a high level of education (Table 3 ).

The type of employment also varies between Aboriginal workers and Canadians as a whole. There are fewer professionals, managers and technicians among Aboriginal workers, but slightly more workers in the services and blue collar sectors. The inequality of the wage distribution among workers in the services sector is greater. One possible explanation of this situation may be that many jobs in this sector are part-time, less specialized, lower paid and thus provide little or no security. On the other hand, there is a higher proportion of Aboriginal workers in the public service sector, a sector of activity with a relatively equal earnings distribution.

9 In most instances, an inequality or polarization measure for men and women together will fall between the inequality measure for men and that for women. For example, the Gini coefficient for all Canadians is 0.407 and is between the Gini coefficient for men (0.373) and that for women (0.408). It is possible, however, for the coefficient for both genders to be higher than the coefficient for men and that for women. For example, the CV for Canadians as a whole (0.634) is higher than the CV for men (0.534) and that for women (0.597). This means that the wage distributions for men and women are far apart from each other and that when the two genders are studied together, there is an even greater gap between the richest and the poorest. (Demographic composition effect; see the section, "Three explanations of the wage dispersion", for more details).

Analytical Studies Branch - Research Paper Series

Statistics Canada No. 11F0019MPE No. 109 
Table 3: Inequality and polarization measures for wage distribution for Canadian workers as a whole by Aboriginal origin, 1991

\begin{tabular}{|c|c|c|c|c|}
\hline & \multicolumn{3}{|c|}{ Inequality measures } & \multirow{2}{*}{$\begin{array}{c}\begin{array}{c}\text { Index of } \\
\text { Polarization }\end{array} \\
\text { FWP }\end{array}$} \\
\hline & Gini & Exp. & $\mathrm{CV}$ & \\
\hline All Canadians & 0.407 & 0.463 & 0.634 & 0.210 \\
\hline \multicolumn{5}{|l|}{ Age groups } \\
\hline 18 to 24 years & 0.458 & 0.485 & 0.814 & 0.280 \\
\hline 25 to 34 years & 0.352 & 0.441 & 0.446 & 0.173 \\
\hline 35 to 54 years & 0.365 & 0.446 & 0.507 & 0.177 \\
\hline 55 to 64 years & 0.407 & 0.463 & 0.680 & 0.200 \\
\hline \multicolumn{5}{|l|}{ Education } \\
\hline primary and secondary & 0.412 & 0.465 & 0.643 & 0.219 \\
\hline SSGD and/or other non-univ. studies & 0.382 & 0.453 & 0.536 & 0.191 \\
\hline university studies & 0.409 & 0.464 & 0.631 & 0.210 \\
\hline \multicolumn{5}{|l|}{ Profession } \\
\hline Managers and professionals & 0.349 & 0.441 & 0.474 & 0.164 \\
\hline Workers in sales and office employees & 0.397 & 0.459 & 0.636 & 0.194 \\
\hline Workers in services & 0.475 & 0.493 & 0.881 & 0.288 \\
\hline $\begin{array}{l}\text { Farmers, growers, breeders and other workers in } \\
\text { the primary sector }\end{array}$ & 0.487 & 0.499 & 0.977 & 0.314 \\
\hline $\begin{array}{l}\text { Workers in transformation industries, building } \\
\text { workers and transportation operation personnel }\end{array}$ & 0.343 & 0.438 & 0.411 & 0.169 \\
\hline Other workers & 0.390 & 0.456 & 0.522 & 0.205 \\
\hline \multicolumn{5}{|l|}{ Sector of activity } \\
\hline Agriculture & 0.486 & 0.498 & 1.153 & 0.282 \\
\hline Forestry and mining operations & 0.392 & 0.457 & 0.563 & 0.200 \\
\hline Construction & 0.379 & 0.451 & 0.557 & 0.190 \\
\hline Manufacturing & 0.350 & 0.441 & 0.459 & 0.167 \\
\hline Distribution services & 0.341 & 0.438 & 0.459 & 0.153 \\
\hline Commercial services & 0.402 & 0.461 & 0.709 & 0.186 \\
\hline Consumer services & 0.463 & 0.487 & 0.909 & 0.263 \\
\hline Public services & 0.364 & 0.446 & 0.466 & 0.181 \\
\hline
\end{tabular}

Sources: Statistics Canada, 1991 Census (PUMF) 
Table 3: Inequality and polarization measures for wage distribution for Canadian workers as a whole by Aboriginal origin, 1991

(continued)

\begin{tabular}{|c|c|c|c|c|}
\hline & \multicolumn{3}{|c|}{ Inequality measures } & \multirow{2}{*}{$\begin{array}{c}\begin{array}{c}\text { Index of } \\
\text { polarization }\end{array} \\
\text { FWP } \\
\end{array}$} \\
\hline & Gini & Exp. & $\mathbf{C V}$ & \\
\hline Canadians with Aboriginal origins & 0.451 & 0.482 & 0.750 & 0.261 \\
\hline \multicolumn{5}{|l|}{ Age groups } \\
\hline 18 to 24 years & 0.490 & 0.500 & 0.956 & 0.320 \\
\hline 25 to 34 years & 0.408 & 0.464 & 0.579 & 0.220 \\
\hline 35 to 54 years & 0.397 & 0.459 & 0.570 & 0.204 \\
\hline 55 to 64 years & 0.396 & 0.459 & 0.589 & 0.199 \\
\hline \multicolumn{5}{|l|}{ Education } \\
\hline primary and secondary & 0.481 & 0.496 & 0.867 & 0.300 \\
\hline SSGD and/or other non-univ. studies. & 0.424 & 0.470 & 0.658 & 0.226 \\
\hline university studies & 0.421 & 0.469 & 0.623 & 0.232 \\
\hline \multicolumn{5}{|l|}{ Profession } \\
\hline Managers and professionals & 0.376 & 0.451 & 0.520 & 0.182 \\
\hline Workers in sales and office employees & 0.422 & 0.470 & 0.678 & 0.222 \\
\hline Workers in services & 0.511 & 0.511 & 1.047 & 0.331 \\
\hline $\begin{array}{l}\text { Farmers, growers, breeders and other workers in } \\
\text { the primary sector }\end{array}$ & 0.523 & 0.518 & 1.072 & 0.357 \\
\hline $\begin{array}{l}\text { Workers in transformation industries, building } \\
\text { workers and transportation operation personnel }\end{array}$ & 0.410 & 0.465 & 0.582 & 0.224 \\
\hline Other workers & 0.458 & 0.486 & 0.754 & 0.294 \\
\hline \multicolumn{5}{|l|}{ Sector of activity } \\
\hline Agriculture & 0.542 & 0.528 & 1.281 & 0.343 \\
\hline Forestry and mining operations & 0.456 & 0.485 & 0.712 & 0.294 \\
\hline Construction & 0.435 & 0.475 & 0.667 & 0.248 \\
\hline Manufacturing & 0.386 & 0.455 & 0.521 & 0.201 \\
\hline Distribution services & 0.370 & 0.449 & 0.526 & 0.174 \\
\hline Commercial services & 0.409 & 0.464 & 0.688 & 0.189 \\
\hline Consumer services & 0.505 & 0.507 & 1.147 & 0.310 \\
\hline Public services & 0.414 & 0.467 & 0.587 & 0.224 \\
\hline
\end{tabular}

Sources: Statistics Canada, 1991 Census (PUMF)

\section{- The gap between the $20 \%$ poorest workers and the $20 \%$ of workers in the middle of the distribution of earnings is substantially wider for Aboriginal workers than for Canadian workers as a whole}

A comparison of mean earnings by quintile shows that workers of Aboriginal origin receive lower wages than Canadian workers as a whole and the difference is even greater for workers of Aboriginal identity. ${ }^{10}$ Mean annual hours worked rise with the wage scale, which means that a worker in the top quintile works more than double the hours of a worker in the bottom quintile. Mean annual hours are

10 It is useful to mention that our findings are minimized because of the greater proportion of Aboriginals without earnings compared to the total Canadian population. 
different for Aboriginal workers than for Canadian workers as a whole, particularly in the bottom and middle quintiles, although they are almost the same in the top quintile. The lower mean hourly and annual wages for Aboriginals do not appear therefore to be attributable to the number of hours worked. Here again, the explanations relating to age and education may enter into the equation.

It is also interesting to look at the ratios of mean annual wages between quintiles. As was mentioned earlier, the gap between the top and bottom quintiles is wider for workers of Aboriginal origin in general and for workers of Aboriginal identity than for Canadian workers as a whole. The difference is mainly due to a greater middle to bottom ratio for the first two groups. In other words, the gap between the $20 \%$ poorest workers and the $20 \%$ of workers in the middle of the distribution is wider for Aboriginals than for Canadian workers as a whole.

Table 4: Wages and hours worked in the bottom, middle and top quintiles in 1991 In addition to earning lower wages, there is a wider gap between the $20 \%$ richest and $20 \%$ poorest workers for Aboriginal workers than for Canadian workers as a whole

\begin{tabular}{|c|c|c|c|c|c|c|}
\hline & Quintiles & $\begin{array}{c}\text { Mean } \\
\text { annual } \\
\text { wage }\end{array}$ & $\begin{array}{c}\text { Mean } \\
\text { annual } \\
\text { hours }\end{array}$ & T/B & $\mathbf{T} / \mathbf{M}$ & $\mathbf{M} / \mathbf{B}$ \\
\hline $\begin{array}{l}\text { Canadian workers as a } \\
\text { whole }\end{array}$ & $\begin{array}{l}\text { Bottom } \\
\text { Middle } \\
\text { Top }\end{array}$ & $\begin{array}{r}\$ 5,600 \\
\$ 26,950 \\
\$ 63,720\end{array}$ & $\begin{array}{l}1050 \\
1930 \\
2180\end{array}$ & 11.5 & 2.4 & 4.8 \\
\hline $\begin{array}{l}\text { Workers of Aboriginal } \\
\text { origin }\end{array}$ & $\begin{array}{l}\text { Bottom } \\
\text { Middle } \\
\text { Top }\end{array}$ & $\begin{array}{r}\$ 3,790 \\
\$ 22,140 \\
\$ 53,490\end{array}$ & $\begin{array}{c}860 \\
1790 \\
2150\end{array}$ & 14.1 & 2.4 & 5.8 \\
\hline $\begin{array}{l}\text { Workers of Aboriginal } \\
\text { identity* } \\
\text { *Taken from APS }\end{array}$ & $\begin{array}{l}\text { Bottom } \\
\text { Middle } \\
\text { Top }\end{array}$ & $\begin{array}{r}\$ 3,080 \\
\$ 19,320 \\
\$ 48,720\end{array}$ & $\begin{array}{c}900 \\
1790 \\
2190\end{array}$ & 15.8 & 2.5 & 6.3 \\
\hline
\end{tabular}

Sources: Statistics Canada, 1991 Census(PUMF) and the Aboriginal Peoples Survey, 1991 (adults file)

\section{- The earnings gap between Canadian workers as a whole and workers of Aboriginal origin increases as earnings increase}

By calculating separately the mean wage by decile for Canadian workers as a whole and for Canadian workers with Aboriginal origins, it is clear that the gap between these two groups increases as earnings increase to the detriment of Aboriginals (Figure 1). The mean wage differential between the two groups is $\$ 1,000$ in the bottom decile in favour of Canadian workers as a whole who earn twice as much. This gap steadily increases to more than $\$ 14,000$ in the top decile of the wage distribution. On the other hand, the relative difference as wages increase tend to stabilize around $20 \%$ in the seventh decile. 
FIGURE 1: The wage gap between Canadian workers as a whole and those of Aboriginal origin increases as earnings increase, 1991

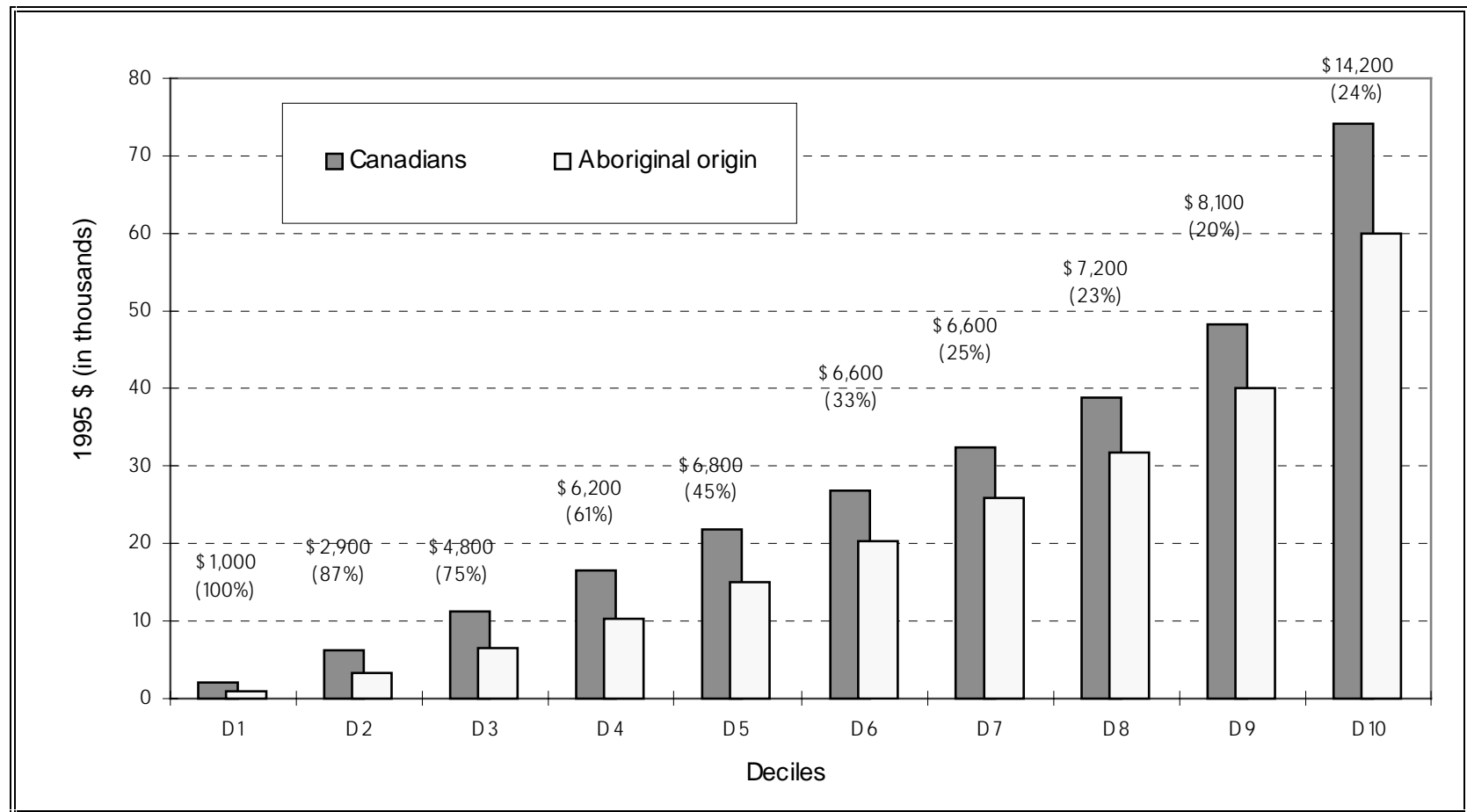

Source: Statistics Canada, 1991 Census (PUMF)

\section{- Inequality and polarization increase when unemployment insurance benefits are added to wages}

Since the employment rate is substantially lower for Aboriginals than for Canadians as a whole, it would be very interesting to repeat the analysis using a larger sample including, in addition to workers with positive annual earnings, individuals whose annual earnings were zero and who were unemployed for 52 weeks. Since the variable "number of weeks of unemployment" is not available, we decided to include in our sample everyone who had either positive annual earnings or positive annual income from unemployment insurance benefits. This is, of course, an imperfect definition since this measure could include individuals who were inactive part of the year. An alternative would be to select men aged 25 to 54 and repeat the analysis for male workers aged 25 to 54 with positive annual earnings comparing them to all men aged 25 to 54 . Unfortunately, this definition is even more likely to include inactive individuals since there is a strong probability that it would include individuals not active in the labour force at all.

When unemployment insurance recipients are combined with workers (Table 5), the wage dispersion widens but the percentage gap ${ }^{11}$ between inequality measures for Aboriginals and Canadian workers as a whole remains virtually the same.

11 Unemployment insurance recipients (now called the employment insurance) did not receive employment income in 1990, but did receive unemployment insurance for that year. 
Table 5: The wage dispersion widens when unemployment insurance recipients are combined with workers, 1991

\begin{tabular}{|c|c|c|c|c|}
\hline & \multicolumn{3}{|c|}{ Inequality measures } & \multirow{2}{*}{$\begin{array}{c}\begin{array}{c}\text { Index of } \\
\text { polarization }\end{array} \\
\text { FWP }\end{array}$} \\
\hline & Gini & Exp. & $\mathbf{C V}$ & \\
\hline All Canadians & 0.423 & 0.470 & 0.679 & 0.222 \\
\hline Men & 0.388 & 0.456 & 0.572 & 0.186 \\
\hline Women & 0.424 & 0.470 & 0.645 & 0.235 \\
\hline Canadians with Aboriginal origins & 0.470 & 0.492 & 0.811 & 0.277 \\
\hline Men & 0.452 & 0.484 & 0.734 & 0.259 \\
\hline Women & 0.469 & 0.491 & 0.788 & 0.284 \\
\hline
\end{tabular}

Sources: Statistics Canada, 1991 Census (PUMF)

\section{- Three explanations of the wage dispersion}

There are three reasons why there may be a wage dispersion within a given population: (1) it may contain a higher proportion of individuals with a relatively high dispersion, such as young workers [inequality due to demographic composition]; (2) mean wage gaps between the various constituent groups of the population, for example, the wage gap between secondary school graduates and university graduates may be higher for Aboriginals than for Canadians as a whole [intergroup inequality]; (3) wage disparity within each of the constituent groups of the population may be higher [intragroup inequality].

To verify these explanations, we broke down the Theil entropy index and the square of the coefficient of variation into cells defined jointly by age and education (Table A2 appended, Column 1), and then separately by profession (Column 2) and sector of activity (Column 3) (Morissette, 1995). ${ }^{12}$ The value of breaking the data down into subgroups is that it makes it possible to identify the portion of the gap attributable to differences in age and education, profession and sector of activity.

For the two inequality measures, variations in the distribution of age and level of education account for between $21 \%$ and $23 \%$ of the difference in the wage inequality between Canadian workers as a whole and workers with Aboriginal origins. This means that for a given age group and level of education, there is greater inequality in the wage dispersion among Aboriginal workers than among Canadian workers as a whole.

It is likely that there are other socio-economic factors that can better explain this gap, including differences in professions, the type of industry and the region. The Theil entropy index and the square of the coefficient of variation were broken down into cells by profession only and by sector of activity

12 Since the square of the coefficient of variation and the Theil entropy index can be broken down, the breakdown was done using these two inequality measures. The formulae used for the breakdown are as follows: the square of the coefficient of variation $C V^{2}=p_{i} c v_{i}^{2} r_{i}^{2}+p_{i}\left(1-r_{i}^{2}\right)$; the Theil entropy index $T E=p_{i} r_{i} \ln \left(r_{i}\right)+p_{i} r_{i} T e_{i}$, where $\mathrm{r}_{\mathrm{i}}=\mathrm{m}_{\mathrm{i}} / \mathrm{m}, \mathrm{m}_{\mathrm{i}}$ represents the mean earnings of group $\mathrm{I}, \mathrm{m}$ represents the overall mean earnings, pi is the proportion of individuals of group $I$ and $\mathrm{cv}_{\mathrm{i}}{ }^{2}$ and $\mathrm{Te}_{\mathrm{i}}$ are the inequality measures for group I. The results were obtained by changing $r_{i}$ first, then changing the inequality measures by group, and lastly by changing $\mathrm{p}_{\mathrm{i}}$. (Taken from Morissette (1995), p.24) For more detail on these measures, please refer to Jenkins, Stephen (1991), "The Measurement of Income Inequality" in Economic Inequality and Poverty: International Perspectives, Lars Osberg (ed), ME Sharpe (Armonk NY and London), pp. 3-38. 
only. The results show that occupation accounts for between $13 \%$ and $15 \%$ of the difference in wage inequality; therefore, for a given profession, there is greater disparity in the wage dispersion among workers with Aboriginal origins than among Canadian workers as a whole. This may be due to the fairly broad classification of occupations used, which is dictated by the limited size of our sample. ${ }^{13}$

As for the sector of activity, it offers no explanation. In other words, for a given sector of activity, the wage dispersion is higher among Aboriginal workers as among Canadian workers as a whole. Clearly, as with the analysis of profession, our results depend on the classification.

\section{IV- Comparison of mean earnings between Aboriginal groups}

Just as Aboriginals are not a homogeneous group in terms of their culture, language or life style, so they are certainly not a homogeneous group in terms of their earnings. This is precisely what Clatworthy et al. (1995) found. They concluded that registered Indians lag far behind other groups of Aboriginal identity. Differences were also found between each of the groups and it was the group of North American Indians living on reserve ${ }^{14,15}$ which was found to be most disparate as a result of its low wages and significant dependence on social transfers (Table 6). For example, the results show that the earnings of North American Indians living on reserve are $44 \%$ lower than those of Métis workers.

We also calculated a regression using the ordinary least squares method including a factor of interaction between gender and the Aboriginal group in order to avoid imposing the same wage differentials on men and women in the various Aboriginal groups. We found that the wage gap between North American Indian men living on reserve and Métis men falls from $40 \%$ to $22 \%$ (see Table A3 appended for the other regressors), while the gap between North American Indian women living on reserve and Métis women falls from $16 \%$ to $12 \%$. These figures indicate that while demographic and socioeconomic differences can explain almost half of the gap among men, they provide little information with respect to women.

13 While we use four major professions in the rest of the text, we have used six (a slightly more refined classification) to break down the Theil entropy index and the square of the coefficient of variation.

14 Almost all North American Indians living on reserve are registered Indians.

15 To identify trends within the various Aboriginal communities, we have divided them into four main groups: North American Indians living on reserve, North American Indians living off reserve, Inuit and Métis. 
Table 6: Mean income by source for Canadian workers who identified as Aboriginal, 1991

\begin{tabular}{|c|c|c|c|c|}
\hline & $\begin{array}{c}\text { North American } \\
\text { Indians on reserve }\end{array}$ & $\begin{array}{c}\text { North American } \\
\text { Indians off reserve }\end{array}$ & Inuit & Métis \\
\hline Wages & $\$ 13,600$ & $\$ 19,700$ & $\$ 17,300$ & $\$ 19,600$ \\
\hline Income from self-employment & $\$ 200$ & $\$ 200$ & $\$ 300$ & $\$ 100$ \\
\hline Investment income & $\$ 100$ & $\$ 200$ & $\$ 100$ & $\$ 100$ \\
\hline Pensions and annuities & - & $\$ 100$ & - & $\$ 100$ \\
\hline Other cash income & $\$ 100$ & $\$ 200$ & $\$ 100$ & $\$ 200$ \\
\hline Family allowances & $\$ 500$ & $\$ 300$ & $\$ 500$ & $\$ 300$ \\
\hline Fed. child tax credit & $\$ 700$ & $\$ 300$ & $\$ 500$ & $\$ 300$ \\
\hline Old age security & - & - & - & - \\
\hline CPP/QPP & - & - & - & - \\
\hline Unemployment insurance benefits & $\$ 1,100$ & $\$ 1,000$ & $\$ 900$ & $\$ 1,200$ \\
\hline Other government transfers & $\$ 1,000$ & $\$ 600$ & $\$ 600$ & $\$ 600$ \\
\hline $\begin{array}{l}\text { Sub-total: } \\
\text { Government transfers }\end{array}$ & $\$ 3,300$ & $\$ 2,200$ & $\$ 2,500$ & $\$ 2,300$ \\
\hline TOTAL INCOME & $\$ 17,300$ & $\$ 22,600$ & $\$ 20,200$ & $\$ 22,500$ \\
\hline
\end{tabular}

Source: Statistics Canada, Aboriginal Peoples Survey, 1991 (adults file)

Table A4 in the Appendices contains the demographic characteristics of each of the four Aboriginal groups and may help explain the earnings differentials between these groups. Let us take the case of North American Indians living on reserve and compare it to North American Indians living off reserve. The findings show that the proportion of young workers aged 18 to 24 is lower on the reserve. We would have expected the opposite to be true since earnings are substantially lower for North American Indians living on reserve. On the other hand, there is also a higher proportion of older workers aged 55 to 64 .

Education certainly provides a more significant explanation since the results show an overrepresentation of North American Indians living off reserve with university education compared to those living on reserve. This is somewhat surprising since reserves have their own primary and secondary education systems, but Aboriginals must then leave their reserves to pursue their studies. In spite of education assistance programs for Aboriginals, it is definitely more difficult for an Aboriginal financially, emotionally and culturally - to leave his reserve to go "to the city" than for any other Canadian who has been educated entirely in the Canadian education system. ${ }^{16}$

There are a great many more blue-collar workers among North American Indians living on reserve and among Inuit compared to the other Aboriginal groups. There are substantial differences with respect to the sector of activity in which workers of Aboriginal identity work. While there is a large concentration of workers from all four Aboriginal groups in the public service sector, six out of every ten North American Indian workers living on reserve work in this sector, or almost double the number in most of the other Aboriginal groups. They are also over-represented in the agricultural sector, probably because of ancestral tradition.

16 Even though education is under provincial jurisdiction, the education system is very similar from province to province and is certainly comparable to the education systems of industrialized countries.

Analytical Studies Branch - Research Paper Series

$-12-$

Statistics Canada No. 11F0019MPE No. 109 
Table A5 appended reveals a relatively small men-women wage differential for North American Indians living on reserve. Since three-quarters of these women and half of the men work in the public service sector, their earnings should be closer than in any other sector.

In short, there are proportionately fewer young North American Indian workers aged 18 to 24 and living on reserve than young workers in the other Aboriginal groups. On average, North American Indians living on reserve have less education than the average Aboriginal and therefore, substantially less than the average Canadian worker. The dominant jobs among North American Indians living on reserve, as well as among Inuit who, for the most part, live in Canada's Far North, are those requiring few skills. Although a community's isolation is likely to translate into lower earnings, the wage gap between men and women is considerably narrower among North American Indians living on reserve.

\section{V-Wage inequality within Aboriginal communities}

In Section III, we documented the differences in earnings inequalities between workers of Aboriginal origin and Canadian workers as a whole. This analysis can hide substantial wage differentials between Aboriginal groups since we found, in the previous section, appreciable wage gaps between these groups. For this reason, it is probable that there is a greater wage dispersion for certain Aboriginal groups. Since this aspect as never been studied before, the purpose of this section is to document differences in wage dispersion for the four main Aboriginal groups. This is the second key objective of our analysis.

\section{- There is greater inequality and polarization in wage distribution for the Inuit}

The four sets of statistics in Table 7 indicate a greater inequality and polarization of wage distribution among the Inuit than for the other Aboriginal peoples. If we look at the wage gap between quintiles, we find that the mean wage is 34 times higher for Inuit in the top quintile than for Inuit in the bottom quintile (Table 8). As was the case for Aboriginal workers as a whole, the largest gap is between the $20 \%$ poorest workers and the $20 \%$ of workers in the middle of the wage distribution. What happens is that Inuit workers in the bottom quintile work fewer hours than the average for Aboriginals in the other groups, but earn a higher hourly wage. These workers may only work part of the year in relatively well-paid professions, such as Inuit carving.

One surprising discovery is that while the wage distribution is on average more unequal for Canadian women and Aboriginals than for men, this gap does not exist for North American Indians living on reserve. ${ }^{17}$ This might lead us to believe that the labour market on reserves is substantially different from the Canadian off-reserve market. ${ }^{18}$ The Inuit not only have a substantially greater wage dispersion than the other Aboriginal groups, they also have the widest gap between the earnings of men and women.

17 The three inequality measures show that the Lorenz curve for women crosses the Lorenz curve for men, which prevents us from concluding that one group is more polarized or more disperse than the other. Refer to Appendix 1 for more details.

18 We are unable to quantify these differences. 
Combining unemployment insurance recipients with workers of Aboriginal origin slightly increases the wage dispersion for the four Aboriginal groups (Table 9). ${ }^{19}$ This approach appears to impact less on the Inuit than on the other Aboriginal groups since the four measures for this group -- which are substantially higher than for the other Aboriginal groups -- experience less of an increase as a result of this combination.

Table 7: Inequality and polarization measures for wage distribution for Aboriginal workers, 1991 ${\text { (summary table })^{20}}^{20}$

\begin{tabular}{|c|c|c|c|c|}
\hline & \multicolumn{3}{|c|}{ Inequality measures } & \multirow{2}{*}{$\frac{\text { Index of polarization }}{\text { FWP }}$} \\
\hline & Gini & Exp. & $\mathrm{CV}$ & \\
\hline North American Indians on reserve & 0.481 & 0.496 & 0.874 & 0.306 \\
\hline Men & 0.482 & 0.496 & 0.896 & 0.308 \\
\hline Women & 0.477 & 0.495 & 0.830 & 0.309 \\
\hline North American Indians off reserve & 0.465 & 0.489 & 0.786 & 0.285 \\
\hline Men & 0.435 & 0.476 & 0.664 & 0.253 \\
\hline Women & 0.471 & 0.492 & 0.819 & 0.307 \\
\hline Inuit & 0.509 & 0.511 & 0.947 & 0.369 \\
\hline Men & 0.479 & 0.497 & 0.801 & 0.317 \\
\hline Women & 0.523 & 0.518 & 1.031 & 0.374 \\
\hline Métis & 0.456 & 0.485 & 0.784 & 0.272 \\
\hline Men & 0.432 & 0.474 & 0.720 & 0.245 \\
\hline Women & 0.452 & 0.482 & 0.731 & 0.258 \\
\hline
\end{tabular}

Source: Statistics Canada, Aboriginal Peoples Survey, 1991 (adults file)

Table 8 Earnings and hours worked in the bottom, middle and top quintiles in 1991 The gap between the $20 \%$ richest and $20 \%$ poorest workers is wider for Inuit workers than for Aboriginal workers as a whole, 1991

\begin{tabular}{|c|c|c|c|c|c|}
\hline & Quintiles & $\begin{array}{c}\text { Mean annual } \\
\text { earnings }\end{array}$ & T/B & T/M & $\mathbf{M} / \mathbf{B}$ \\
\hline $\begin{array}{l}\text { North American Indians on } \\
\text { reserve }\end{array}$ & $\begin{array}{l}\text { Bottom } \\
\text { Middle } \\
\text { Top }\end{array}$ & $\begin{array}{c}\$ 1,320 \\
\$ 10,140 \\
\$ 34,030\end{array}$ & 25.8 & 3.4 & 7.7 \\
\hline $\begin{array}{l}\text { North American Indians off } \\
\text { reserve }\end{array}$ & $\begin{array}{l}\text { Bottom } \\
\text { Middle } \\
\text { Top }\end{array}$ & $\begin{array}{c}\$ 1,770 \\
\$ 15,680 \\
\$ 48,100\end{array}$ & 27.2 & 3.1 & 8.9 \\
\hline Inuit & $\begin{array}{l}\text { Bottom } \\
\text { Middle } \\
\text { Top }\end{array}$ & $\begin{array}{l}\$ 1,330 \\
\$ 11,900 \\
\$ 44,980\end{array}$ & 33.8 & 3.8 & 8.9 \\
\hline Métis & $\begin{array}{l}\text { Bottom } \\
\text { Middle } \\
\text { Top } \\
\end{array}$ & $\begin{array}{c}\$ 2,010 \\
\$ 15,730 \\
\$ 47,360 \\
\end{array}$ & 23.5 & 3.0 & 7.8 \\
\hline
\end{tabular}

Source: Statistics Canada, Aboriginal Peoples Survey, 1991 (adults file)

19 See Table A7 appended for comparison with Table 9.

20 Refer to Table A6 appended for the socio-demographic details. 
Table 9: Inequality and polarization measures for the wage distribution of workers and unemployment insurance recipients of Aboriginal origin, 1991

\begin{tabular}{|c|c|c|c|c|}
\hline & \multicolumn{3}{|c|}{ Inequality measures } & \multirow{2}{*}{$\begin{array}{c}\text { Index of polarization } \\
\text { FWP }\end{array}$} \\
\hline & Gini & Exp. & CV & \\
\hline North American Indians on reserve & 0.508 & 0.510 & 0.985 & 0.340 \\
\hline Men & 0.512 & 0.512 & 1.021 & 0.342 \\
\hline Women & 0.502 & 0.508 & 0.930 & 0.346 \\
\hline North American Indians off reserve & 0.492 & 0.503 & 0.883 & 0.329 \\
\hline Men & 0.462 & 0.489 & 0.750 & 0.280 \\
\hline Women & 0.497 & 0.505 & 0.916 & 0.325 \\
\hline Inuit & 0.528 & 0.521 & 1.032 & 0.382 \\
\hline Men & 0.499 & 0.507 & 0.875 & 0.353 \\
\hline Women & 0.540 & 0.528 & 1.116 & 0.423 \\
\hline Métis & 0.484 & 0.498 & 0.879 & 0.305 \\
\hline Men & 0.464 & 0.490 & 0.836 & 0.290 \\
\hline Women & 0.480 & 0.496 & 0.825 & 0.288 \\
\hline
\end{tabular}

Source: Statistics Canada, Aboriginal Peoples Survey, 1991 (adults file)

\section{VI- Conclusion}

This study confirms the findings of earlier studies and the general belief that, on average, Aboriginal peoples earn less that Canadians as a whole. Our study did, however, generate new findings: there is greater inequality in the distribution of wages for Aboriginal workers than for Canadian workers as a whole, even after allowing for demographic differences. Not only do Aboriginals earn lower wages than Canadians as a whole (for comparable work) -- intergroup inequality -- but they also experience a more unequal wage distribution -- intragroup inequality.

Knowledge of the wage distribution at the individual level is necessary to understand the success of individuals in the labour force. However, an examination of the family income would be required to understand more fully the situation of Aboriginals compared to Canadians as a whole. It is this aspect that we would like to explore in another study using the 1996 Census data. ${ }^{19}$ We would then be able to answer the following questions: (1) Is family income more polarized for Aboriginals than for Canadians?; (2) Do transfer payments have a more equalizing effect for Aboriginals than for Canadians as a whole?

19 The 1996 Census contains both definitions of Aboriginal status (Aboriginal origins and Aboriginal identity), which will enable us to make interesting comparisons. 


\section{References}

Indian and Northern Affairs Canada (INAC). Bill C-31, Fact sheet N², September 1995.

Beach, Charles M. and George A. Slotsve. "Are We Becoming Two Societies? Income Polarization and the Myth of the Declining Middle Class in Canada.", The Social Policy Challenge 12, C.D. Howe Institute, Toronto, 1996.

Clatworthy et al. "Patterns of Employment, Unemployment and Poverty (Part One)." Final report presented by Four Directions Consulting Group to the Royal Commission on Aboriginal Peoples, January 1995.

Drost, Helmar. "The Aboriginal-White Unemployment Gap in Canada's Urban Labor Markets" in Market Solutions for Native Poverty: Social Policy for the Third Solitude, The Social Policy Challenge 11, John Richards and William G. Watson, Series Co-Editors, C.D. Howe Institute, 1995.

George, P. et al. "Patterns of Employment, Unemployment and Poverty (Part Two): A Comparative Analysis of Several Aspects of the Employment Experience of Aboriginal and Non-Aboriginal Canadians Using 1991 Census Public Use Microdata." First complete version of the report presented to the Royal Commission on Aboriginal Peoples, September 30, 1994.

George, Peter and Kuhn, Peter. The Size and Structure of Native-White Wage Differentials in Canada, Canadian Journal of Economics, XXVII, No. 1, February 1994.

Leblanc, Greg. Discrimination in the Labour Market. Canadian Journal of Economics, XXVIII, No.3, August 1995.

Jenkins, Stephen (1991). "The Measurement of Income Inequality" in Economic Inequality and Poverty: International Perspectives, Lars Osberg (ed), ME Sharpe (Armonk NY et London), pp. 3-38.

Morissette, R. "Why Has Inequality in Weekly Earnings Increased in Canada?", Research Paper Series No. 80, Analytical Studies Branch, Statistics Canada, July 1995.

Morissette, R. et al. (1994a). "What is Happening to Earnings Inequality in Canada?", Research Paper Series No.60, Analytical Studies Branch, Statistics Canada, June 1994.

Morissette, R. and Bérubé, C. "Longitudinal Aspects of Earnings Inequality in Canada", Research Paper Series No.94, Analytical Studies Branch, Statistics Canada, July 1996.

Morissette, R. and Sunter, D. (1994b). "What is Happening to Weekly Hours Worked in Canada?", Research Paper Series No.65, Analytical Studies Branch, Statistics Canada, July 1994.

Parent, Pierre. Comparaison du nombre et des caractéristiques des autochtones selon le Recensement de 1991 et selon l'Enquête auprès des peuples autochtones de 1991. Interim version, Employment Equity Data Program, September 27, 1995. 
Pendakur Krishna and Pendakur, Ravi. The Colour of Money: Earnings Differentials Among Ethnic Groups in Canada, Strategic Research and Analysis, Department of Canadian Heritage, June 1996.

The MIT Dictionary of Modern Economics, $3^{\mathrm{e}}$ ed., David W. Pearce (ed.), The MIT Press, 1989, p. 462

Wolfson, Michael C. "Divergent Inequalities - Theory, Empirical Results and Prescriptions", Research Paper Series No. 66, Analytical Studies Branch, Statistics Canada, May 1995. 


\section{Appendix 1: Concepts, definitions and data sources}

\section{Target population}

Since the purpose of our study is to examine the position of Aboriginal workers in the labour market, our target population is all persons aged 18 to $64^{21}$ who worked a minimum of one week and received positive employment income during the reference year.

\section{Aboriginal population}

As was mentioned in the review of earlier studies (Section II), the definition of Aboriginal varies depending on the information source used. The 1991 Census used the concept of Aboriginal origins, that is, any Canadian who reported Aboriginal origins on the Census is considered to be an Aboriginal. The number of Aboriginal rose dramatically between 1986 and 1991, climbing from around 700,000 to more than 1 million. Only a small portion of the $40 \%$ increase in the number of Aboriginal peoples can be explained by the high birth rate among Aboriginal women. It would seem that the change in the Indian Act in 1990 prompted persons with Aboriginal origins to declare them (see inset A1). For this reason, we have restricted our analysis to 1991.

The definition of Aboriginal used for the 1991 Aboriginal Peoples Survey (APS) is considerably more restrictive since it is based on whether the individual identified with one of the Aboriginal peoples. In actual fact, only 6 out of every 10 people who reported Aboriginal origins in 1991 identified with one of the Aboriginal peoples. Since comparisons between Aboriginals and the whole of the Canadian population must be based on the Census ${ }^{22}$, we make only a brief comparison of the two Aboriginal concepts for 1991, that is, the concept of Aboriginal origin and the concept of Aboriginal identity.

The 1991 Census is therefore used to analyse the extend of the over-representation of Aboriginal peoples at the bottom of the wage and income distributions and their under-representation at the top of these distributions. Once the 1996 Census data is available, we will be able to make a comparative analysis of 1991 and 1996 using the two concepts of Aboriginal status, that of Aboriginal origins and that of Aboriginal identity.

We have used two definitions of Aboriginal status depending on the question being considered in order to make the most of the two data bases used in this study. When the comparison is between Aboriginals and the Canadian population as a whole, the target population consists of all Canadians who reported Aboriginal origins. In such instances, the data has been taken from the Public Use Microdata Files (PUMF) of the 1991 Census.

When our analysis involves a comparison among the various Aboriginal peoples, most of the data has been supplied by the 1991 Aboriginal Peoples Survey (APS) -- a postcensal survey -- which enables us to go into greater detail. For example, the PUMFs of the various census do not enable us to study the four main Aboriginal groups. They restrict us to dividing Aboriginals into only two groups, North American Indians and others. These are the divisions used in the majority of Aboriginal studies (Drost, 1995; George, 1994). While the APS data does not accommodate a trend analysis, it does bring

${ }^{21}$ We have arbitrarily defined 18 to 64 years as the population of working age.

${ }^{22}$ Everyone answered the same questions on both questionnaires.

Analytical Studies Branch - Research Paper Series

$-18$

Statistics Canada No. 11F0019MPE No. 109 
considerable added value to this study. The concept of considering as Aboriginal only those individuals who identify with one of the main Aboriginal peoples ensures that only those with the characteristics associated with Aboriginal peoples are considered (Parent, 1995). If this study shows that Aboriginals who identify themselves as such (slightly more than 600,000 people) have less success in the labour market than all Canadians with Aboriginal origins (there are one million), then that could have major repercussions on the analysis of the impact of certain social programs directed at Aboriginals.

As was mentioned earlier, our study compares Aboriginal peoples to each other and to the Canadian population as a whole using an exhaustive series of inequality and polarization measures to fully interpret the labour market phenomena associated with Aboriginals. These measures are calculated for earnings only since the study of total income must be conducted at the family rather than the individual level.

\section{Data limitations}

In 1991, 78 Indian reserves and settlements were only partly counted. It was therefore decided to exclude these reserves and settlements from the Census database to ensure that the published results met the Census quality standards. The specific number of individuals affected by this exclusion is unknown, although an internal estimate puts the number at about 37,000 (Parent, 1995).

In addition to the problem with partially counted reserves and settlements, there is also the problem of the undercounting which affects all Census populations, but which is especially high on the reserves. It is possible that when all of these factors are combined, the undercount of the on-reserve population could be as high as $25 \%$. This caution is important given that the characteristics of the people living on Indian reserves and in settlements can sometimes differ from those of other people and even from those of other Aboriginals (taken from Parent, 1995). 


\begin{abstract}
Summary of the changes in the Indian Act
The Canadian parliament adopted Bill C-31 on June 28, 1985 (INAC, 1995). The amendments to the Indian Act were based on three fundamental principles:

$\diamond$ elimination of discrimination;

$\checkmark$ reinstatement of Indian status (of those who had lost that status either through discrimination or emancipation) and the right to belong to a band;

$\diamond$ increased control by Indian bands of their own affairs.

Consequences of the change in the Indian Act

The amendments to the Indian Act prompted an increase in individuals reporting Aboriginal origins. As a result, an accurate Aboriginal trend analysis for 1986 to 1991 is not possible.

Let us take as an example the case where our study shows that the one million Aboriginals reporting on the 1991 Census (concept of Aboriginal origins) are more financially well off than the 600,000 Aboriginals who identified in the 1991 APS (concept of Aboriginal identity). In this instance, it is possible to deduce that the 400,000 individuals who represent the difference between the two definitions of Aboriginal status are substantially more affluent than the 600,000 Aboriginals who identified with an Aboriginal people and do not possess any of the Aboriginal characteristics (Parent, 1995).

$\begin{array}{lcc}\text { Aboriginal origins } & 1 \text { million } & \$ 18,800 \\ \text { Aboriginal identity } & 600,000 & \$ 15,700 \\ & & \\ \text { Sources: Statistics Canada, } & 1991 \text { Census (PUMF) and Aboriginal Peoples Survey, } 1991\end{array}$

\section{Total number Mean total income (18-64 years)}

\begin{tabular}{|lcc} 
Aboriginal origins & 1 million & $\$ 18,800$ \\
Aboriginal identity & 600,000 & $\$ 15,700$ \\
& & \\
Sources: Statistics Canada, & 1991 Census (PUMF) and Aboriginal Peoples Survey, 1991
\end{tabular}
\end{abstract}

\title{
Definition of income
}

In order to simplify the paper, only the analysis of wages for workers aged 18 to 64 is presented in this study.

Nevertheless, Section III contains a table showing mean income-- by income type -- of workers aged 18 to 64. In this instances, total income consists of wages, income from self-employment, government transfers (which are described below), investment income, pensions and annuities, and any other cash income. Government transfers include family allowances, federal child tax credits, unemployment insurance benefits, old age security pensions and guaranteed income supplements, Canada and Quebec Pension Plan benefits, and any other income from public sources. It is understood that income from Old Age Security and Guaranteed Income Supplement benefits, and from Canada and Quebec Pension Plans are minimal since the study focuses on the population of working age, that is, 18 to 64 years.

Also note that all variables making up the total income refer to income earned in 1990. Incomes were indexed to incomes for the year 1995 using the Consumer Price Index (CPI). 
Lastly, consideration must also be given to the economic cycle in our examination of income received in 1990. The employment level was at its peak in 1990, just as the last recession was beginning.

\section{Geographic areas}

Two approaches were used to study the geographical aspects of wage inequality among Aboriginal peoples. The first consists of the Atlantic Region, Quebec, Ontario, the Prairies, British Columbia and the Canadian North. The second construction compares Aboriginals living in rural settings to those living in urban settings.

The first geographic construction (the six regions) has to be used in comparisons between Aboriginals and the Canadian population as a whole because there is no variable to determine whether a person lives in a rural or urban setting in the 1991 Census PUMF.

We chose to use the formula of the six major regions of Canada rather than to compare peoples by province because Aboriginal peoples often live in areas, which overlap more than one province. It is also very appropriate to study Aboriginal peoples by region since researchers have found that Aboriginals represent a greater portion of the population in the West than elsewhere in Canada and their economic situation also appears to be less favourable in that part of the country (Drost, 1995).

\section{Other variables}

The education variables refers to the highest level of education achieved. Given the small size of some Aboriginal groups, we have divided the level of education to three parts: primary or secondary studies only (no diploma), secondary school graduating diploma and/or other non-university studies and university studies.

The occupation variable ${ }^{23}$ is broken down into four professional groups: managers and professionals (directors; managers; administrators; workers in natural science, engineering and mathematics; workers in specializing in social sciences; medical and health educators; professionals in the arts and literature fields), technicians and workers specializing in sales, workers specializing in services and blue collar workers (farmers; other primary sector workers; workers specializing in product manufacturing, assembly and repair; building workers; transportation operation personnel).

The industry variable ${ }^{24}$ is divided into two major industries given the small size of some Aboriginal groups. They are the primary and secondary sectors industry and the services industry.

\section{Inequality and polarization measures}

It was necessary to carry out a whole series of inequality and polarization measures in order to fully describe the shifts in wage inequality and polarization. A reasonable choice is to use an inequality measure that is sensitive to the bottom (exponential measure), middle (Gini coefficient) and top (coefficient of variation) of income distribution. If all three measures produce the same conclusion when comparing two income distributions, it can be expected -- to some degree -- that their Lorenz

23 According to the 1980 Standard Occupational Classification.

24 According to the 1980 Standard Industrial Classification.

Analytical Studies Branch - Research Paper Series

Statistics Canada No. 11F0019MPE No. 109 
curves will not cross which would make it possible to draw conclusions on the results. However, if the three measures do not agree, the Lorenz curves will cross and it is not possible to do any definite ranking (Wolfson, 1995). We added the FWP index of polarization to these measures and/or a measure related to polarization such as the deviation around the median. ${ }^{25}$

25 For more detail, refer to Jenkins, Stephen (1991) "The Measurement of Income Inequality" in Economic Inequality and Poverty: International Perspectives, Lars Osberg (ed), ME Sharpe (Armonk NY and London), pp. 3-38. 


\section{Appendix 2: Tables}

Table A1: Distribution of Canadian workers by Aboriginal origins, 1991 Aboriginals have more workers in public services

\begin{tabular}{||lcc||}
\hline \hline & All Canadians & $\begin{array}{c}\text { Canadians with Aboriginal } \\
\text { origins }\end{array}$ \\
\hline & $(\boldsymbol{\%})$ & $(\boldsymbol{\%})$ \\
EDUCATION & & 34.9 \\
Primary or secondary & 25.3 & 47.3 \\
SSGD and/or other non-university studies & 48.1 & 17.8 \\
University studies & 26.6 & \\
& & 23.3 \\
PROFESSION & & 23.9 \\
Managers and professionals & 28.7 & 18.5 \\
Workers in sales and office employees & 27.6 & 5.7 \\
Workers in services & 13.8 & 22.6 \\
Farmers, growers, breeders and other primary & 3.3 & 6.1 \\
sector workers & & \\
Workers in transformation industries, building & 20.5 & \\
workers and transportation operation personnel & & \\
Other workers & & \\
& 5.0 & 1.7 \\
SECTOR OF ACTIVITY & & 5.1 \\
Agriculture & & 7.6 \\
Forestry and mining operations & 2.0 & 10.8 \\
Construction & 2.6 & 10.7 \\
Manufacturing & 6.3 & 7.7 \\
Distribution services & 15.4 & 24.2 \\
Commercial services & 12.1 & 32.2 \\
Consumer services & 11.3 & \\
Public services & 24.1 & \\
& 25.0 & \\
\hline \hline
\end{tabular}

Source: Statistics Canada, 1991 Census (PUMF)

26 The "other workers" category includes handlers, other skilled workers and machine operators, members of the clergy and workers not classified elsewhere. 
Table A2: Explanations of wage dispersion, 1991

I-Inequality measures for all Canadian and Aboriginal workers

\begin{tabular}{|lccc|}
\hline Canadians & Aboriginals & $\begin{array}{c}\text { Variation in inequality } \\
\text { between Canadians and } \\
\text { Aboriginals }\end{array}$ \\
\hline Index of Theil entropy & 0.299 & 0.360 & 0.061 \\
Square of the coefficient of variation & 0.652 & 0.763 & 0.111 \\
\hline
\end{tabular}

II- Percentage of deviation in the inequality of annual wages attributable to variations in inequality between the groups, variations in inequality within the groups and variations in demographic weightings ${ }^{1}$

\begin{tabular}{|c|c|c|c|}
\hline & (1) & (2) & (3) \\
\hline Breakdown by: & $\begin{array}{l}\text { age and } \\
\text { education }\end{array}$ & profession & sector of activity ${ }^{2}$ \\
\hline \multicolumn{4}{|l|}{ Index of Theil entropy } \\
\hline \multicolumn{4}{|l|}{ Variation: } \\
\hline in intragroup inequality & $80.3 \%$ & $90.2 \%$ & $95.1 \%$ \\
\hline in demographic weightings & $21.3 \%$ & $13.1 \%$ & $0 \%$ \\
\hline \multicolumn{4}{|l|}{ Square of the coefficient of variation } \\
\hline $\begin{array}{l}\text { Variation: } \\
\text { in inequality between grouns }\end{array}$ & & & $72 \%$ \\
\hline in intragroup inequality & $\begin{array}{l}-5.4 \% \\
82.0 \%\end{array}$ & $\begin{array}{l}-0.1 \% \\
92.8 \%\end{array}$ & $98.2 \%$ \\
\hline in demographic weightings & $23.4 \%$ & $15.3 \%$ & $-5.4 \%$ \\
\hline
\end{tabular}

Source: Statistics Canada, 1991 Census (PUMF) 
Table A3: Results of the regression by the ordinary least squares method on workers who identified as Aboriginal, 1991

\begin{tabular}{|c|c|c|c|c|}
\hline & Variable & Coefficient & $\begin{array}{l}\text { Standard } \\
\text { deviation }\end{array}$ & $\mathbf{T}$ \\
\hline \multirow{5}{*}{$\begin{array}{l}\text { ABORIGINAL } \\
\text { GROUPS }\end{array}$} & Constant & 3.7779 & 0.0616 & $61.334 \dagger$ \\
\hline & Women & -0.2447 & 0.0339 & $-7.221 \dagger$ \\
\hline & NAI-on reserve & -0.2224 & 0.0263 & $-8.440 \dagger$ \\
\hline & NAI-off reserve & -0.0138 & 0.0284 & -0.487 \\
\hline & Inuit & 0.0456 & 0.0370 & 1.234 \\
\hline INTERACTION & Women NAI-on reserve & 0.1001 & 0.0373 & $2.682 \dagger$ \\
\hline BETWEEN WOMEN & Women NAI-off reserve & 0.0134 & 0.0403 & 0.333 \\
\hline AND ABOR. GR. & Inuit women & 0.0413 & 0.0501 & 0.825 \\
\hline \multirow[t]{3}{*}{ AGE } & Age 25-34 & 0.4117 & 0.0188 & $21.897 \dagger$ \\
\hline & Age 35-54 & 0.5507 & 0.0189 & $29.192 \dagger$ \\
\hline & Age 55-64 & 0.5844 & 0.0335 & $17.144 \dagger$ \\
\hline \multirow[t]{2}{*}{ EDUCATION } & $\begin{array}{l}\text { SSGD* and other non-univ. } \\
\text { studies }\end{array}$ & 0.1188 & 0.0137 & $8.671 \dagger$ \\
\hline & University studies & 0.2517 & 0.0224 & $11.232 \dagger$ \\
\hline \multirow[t]{5}{*}{ PROFESSION } & Managers and professionals & 0.1601 & 0.0202 & $7.921 \dagger$ \\
\hline & $\begin{array}{l}\text { Technicians, workers in sales and } \\
\text { office employees }\end{array}$ & -0.0513 & 0.0221 & $-2.321 *$ \\
\hline & Workers in services & -0.2180 & 0.0224 & $-9.717 \dagger$ \\
\hline & $\begin{array}{l}\text { Workers in transformation } \\
\text { industries, building workers } \\
\text { and transportation operation } \\
\text { personnel }\end{array}$ & -0.1410 & 0.0308 & $-4.575 \dagger$ \\
\hline & Other workers & -0.1450 & 0.0493 & $-2.938 \dagger$ \\
\hline \multirow[t]{6}{*}{ INDUSTRY } & Agriculture & -0.0461 & 0.0390 & -1.183 \\
\hline & Forestry and mining oper. & 0.2415 & 0.0381 & $6.344 \dagger$ \\
\hline & Construction & 0.1199 & 0.0572 & $2.095^{*}$ \\
\hline & Distribution services & 0.0357 & 0.0281 & 1.273 \\
\hline & Commercial services & 0.1868 & 0.0251 & $7.430 \dagger$ \\
\hline & Public services & -0.2107 & 0.0222 & $-9.506 \dagger$ \\
\hline HOURS & Log of hours worked & 0.7442 & 0.0078 & $95.696 \dagger$ \\
\hline \multirow{5}{*}{ REGION } & Atlantic & 0.0240 & 0.0286 & 0.837 \\
\hline & Quebec & 0.1463 & 0.0220 & $6.646 \dagger$ \\
\hline & Ontario & 0.0907 & 0.0192 & $4.728 \dagger$ \\
\hline & British Columbia & 0.0954 & 0.0191 & $4.994 \dagger$ \\
\hline & Yukon and NWT & 0.1627 & 0.0246 & $6.616 \dagger$ \\
\hline
\end{tabular}

Source: Statistics Canada, Aboriginal Peoples Survey, 1991 (adults file)

*: significant to $5 \%$

$\dagger$ : significant to $1 \%$ 
Table A4: Distribution of Canadian workers by Aboriginal identity, 1991

\begin{tabular}{|c|c|c|c|c|}
\hline & $\begin{array}{c}\text { North } \\
\text { American } \\
\text { Indians on } \\
\text { reserve }\end{array}$ & $\begin{array}{c}\text { North } \\
\text { American } \\
\text { Indians off } \\
\text { reserve }\end{array}$ & Inuit & Métis \\
\hline MEN AND WOMEN & $(\%)$ & $(\%)$ & $(\%)$ & $(\%)$ \\
\hline \multicolumn{5}{|l|}{ AGE } \\
\hline 18 to 24 years & 19.4 & 23.9 & 27.9 & 22.2 \\
\hline 25 to 34 years & 35.7 & 36.6 & 37.9 & 37.0 \\
\hline 35 to 54 years & 39.2 & 35.6 & 29.3 & 35.8 \\
\hline 55 to 64 years & 5.7 & 3.9 & 4.9 & 5.0 \\
\hline \multicolumn{5}{|l|}{ EDUCATION } \\
\hline primary or secondary & 49.0 & 36.0 & 47.0 & 40.0 \\
\hline SSGD and/or other non-university studies & 40.7 & 47.9 & 40.9 & 47.0 \\
\hline university studies & 8.5 & 15.6 & 4.0 & 12.5 \\
\hline \multicolumn{5}{|l|}{ PROFESSION } \\
\hline Managers and professionals & 23.5 & 19.3 & 17.8 & 18.4 \\
\hline Workers in sales and office employees & 11.7 & 24.4 & 20.1 & 20.0 \\
\hline Workers in services & 15.6 & 17.6 & 17.6 & 19.4 \\
\hline $\begin{array}{l}\text { Farmers, growers, breeders and other primary } \\
\text { sector workers }\end{array}$ & 10.7 & 5.3 & 2.5 & 6.1 \\
\hline $\begin{array}{l}\text { Workers in transformation industries, building } \\
\text { workers and transportation operation personnel }\end{array}$ & 1.4 & 1.2 & 5.1 & 1.2 \\
\hline Other workers & 31.5 & 28.4 & 33.1 & 31.2 \\
\hline \multicolumn{5}{|l|}{ SECTOR OF ACTIVITY } \\
\hline Agriculture & 6.1 & 3.7 & 1.9 & 4.2 \\
\hline Forestry and mining operations & 2.8 & 4.0 & 3.0 & 6.1 \\
\hline Construction & 1.2 & 1.4 & - & 1.0 \\
\hline Manufacturing & $\dagger$ & $\dagger$ & $\dagger$ & $\dagger$ \\
\hline Distribution services & 8.5 & 12.4 & 8.1 & 13.2 \\
\hline Commercial services & 3.9 & 15.4 & 14.7 & 13.2 \\
\hline Consumer services & 3.7 & 6.8 & 10.8 & 8.2 \\
\hline Public services & 61.5 & 35.0 & 44.4 & 35.3 \\
\hline
\end{tabular}

Source: Statistics Canada, Aboriginal Peoples Survey, 1991 (adults file)

$\dagger$ : The APS shows no worker of Aboriginal identity in the manufacturing sector.

*: The total does not equal $100 \%$ because the numbers have been rounded off and because certain professions and sectors of activity have been excluded. 
Table A4: Distribution of Canadian workers by Aboriginal identity, 1991 (continued)

\begin{tabular}{|c|c|c|c|c|}
\hline & $\begin{array}{c}\text { North } \\
\text { American } \\
\text { Indians on } \\
\text { reserve }\end{array}$ & $\begin{array}{c}\text { North } \\
\text { American } \\
\text { Indians off } \\
\text { reserve }\end{array}$ & Inuit & Métis \\
\hline MEN & $(\%)$ & $(\%)$ & $(\%)$ & $(\%)$ \\
\hline \multicolumn{5}{|l|}{ AGE } \\
\hline 18 to 24 years & 18.9 & 25.2 & 26.5 & 21.0 \\
\hline 25 to 34 years & 34.7 & 38.0 & 37.8 & 36.2 \\
\hline 35 to 54 years & 40.0 & 32.7 & 29.5 & 38.1 \\
\hline 55 to 64 years & 6.5 & 4.2 & 6.2 & 5.3 \\
\hline \multicolumn{5}{|l|}{ EDUCATION } \\
\hline primary or secondary & 53.6 & 40.4 & 47.4 & 43.6 \\
\hline SSGD and/or other non-university studies & 38.7 & 45.8 & 42.2 & 46.8 \\
\hline university studies & 5.4 & 13.1 & 3.1 & 9.0 \\
\hline \multicolumn{5}{|l|}{ Profession } \\
\hline Managers and professionals & 16.7 & 13.5 & 13.1 & 12.7 \\
\hline Workers in sales and office employees & 4.2 & 12.4 & 10.8 & 10.4 \\
\hline Workers in services & 9.7 & 11.2 & 8.8 & 11.0 \\
\hline $\begin{array}{l}\text { Farmers, growers, breeders and other primary } \\
\text { sector workers }\end{array}$ & 15.9 & 9.1 & 4.1 & 10.2 \\
\hline $\begin{array}{l}\text { Workers in transformation industries, building } \\
\text { workers, transportation operation personnel }\end{array}$ & 1.6 & 1.3 & 3.9 & 1.3 \\
\hline Other workers & 46.2 & 48.9 & 55.5 & 50.9 \\
\hline \multicolumn{5}{|l|}{ SECTOR OF ACTIVITY } \\
\hline Agriculture & 8.7 & 5.8 & 3.0 & 6.3 \\
\hline Forestry and mining operations & 2.8 & 5.8 & 4.0 & 8.8 \\
\hline Construction & 1.8 & 2.6 & - & 1.3 \\
\hline Manufacturing & $\dagger$ & $\dagger$ & $\dagger$ & $\dagger$ \\
\hline Distribution services & 12.9 & 21.3 & 12.6 & 21.9 \\
\hline Commercial services & 3.6 & 12.9 & 14.4 & 15.6 \\
\hline Consumer services & 4.7 & 9.7 & 14.4 & 4.9 \\
\hline Public services & 53.0 & 19.7 & 35.1 & 52.0 \\
\hline
\end{tabular}

Source: Statistics Canada, Aboriginal Peoples Survey, 1991 (adults file)

$\dagger$ : The APS shows no worker of Aboriginal identity in the manufacturing sector.

Note: The total does not equal $100 \%$ because the numbers have been rounded off and because certain professions and sectors of activity have been excluded. 
Table A4: Distribution of Canadian workers by Aboriginal identity, 1991 (continued and end)

\begin{tabular}{|c|c|c|c|c|}
\hline & $\begin{array}{c}\text { North } \\
\text { America } \\
\text { Indians on } \\
\text { reserve }\end{array}$ & $\begin{array}{c}\text { North } \\
\text { American } \\
\text { Indians off } \\
\text { reserve }\end{array}$ & Inuit & Métis \\
\hline WOMEN & $(\%)$ & $(\%)$ & $(\%)$ & $(\%)$ \\
\hline \multicolumn{5}{|l|}{ AGE } \\
\hline 18 to 24 years & 20.3 & 22.7 & 29.5 & 23.5 \\
\hline 25 to 34 years & 37.2 & 35.2 & 38.0 & 37.9 \\
\hline 35 to 54 years & 38.1 & 38.5 & 29.2 & 33.3 \\
\hline 55 to 64 years & 4.5 & 3.6 & 3.4 & 5.3 \\
\hline \multicolumn{5}{|l|}{ EDUCATION } \\
\hline Primary or secondary & 41.9 & 31.7 & 46.6 & 36.2 \\
\hline SSGD and/or other non-university studies & 43.7 & 50.0 & 39.4 & 47.3 \\
\hline University studies & 13.1 & 18.0 & 5.2 & 16.4 \\
\hline \multicolumn{5}{|l|}{ Profession } \\
\hline Managers and professionals & 33.8 & 24.9 & 23.3 & 24.6 \\
\hline Workers in sales and office employees & 23.2 & 35.8 & 31.1 & 30.6 \\
\hline Workers in services & 24.4 & 23.7 & 28.0 & 28.6 \\
\hline $\begin{array}{l}\text { Farmers, growers, breeders and other primary } \\
\text { sector workers }\end{array}$ & 2.7 & 1.2 & 0.5 & 1.5 \\
\hline $\begin{array}{l}\text { Workers in transformation industries, building } \\
\text { workers and transportation operation workers }\end{array}$ & 1.2 & 1.1 & 6.6 & 1.0 \\
\hline Other workers & 9.1 & 8.7 & 6.7 & 9.6 \\
\hline \multicolumn{5}{|l|}{ SECTOR OF ACTIVITY } \\
\hline Agriculture & 2.0 & 1.8 & 0.6 & 2.0 \\
\hline Forestry and mining operations & 2.7 & 2.3 & 1.8 & 3.0 \\
\hline Construction & - & - & - & 0.7 \\
\hline Manufacturing & $\dagger$ & $\dagger$ & $\dagger$ & $\dagger$ \\
\hline Distribution services & 1.7 & 3.9 & 2.9 & 3.7 \\
\hline Commercials services & 4.3 & 17.8 & 15.0 & 15.6 \\
\hline Consumer services & 2.1 & 4.1 & 6.5 & 4.9 \\
\hline Public services & 74.6 & 49.7 & 55.2 & 52.0 \\
\hline
\end{tabular}

Source: Statistics Canada, Aboriginal Peoples Survey, 1991 (adults file)

$\dagger$ : The APS shows no worker of Aboriginal identity in the manufacturing sector.

Note: The total does not equal $100 \%$ because the numbers have been rounded off and because certain professions and sectors of activity have been excluded. 
Table A5: Wage inequality increases when unemployment insurance recipients are combined with Aboriginal workers, 1991

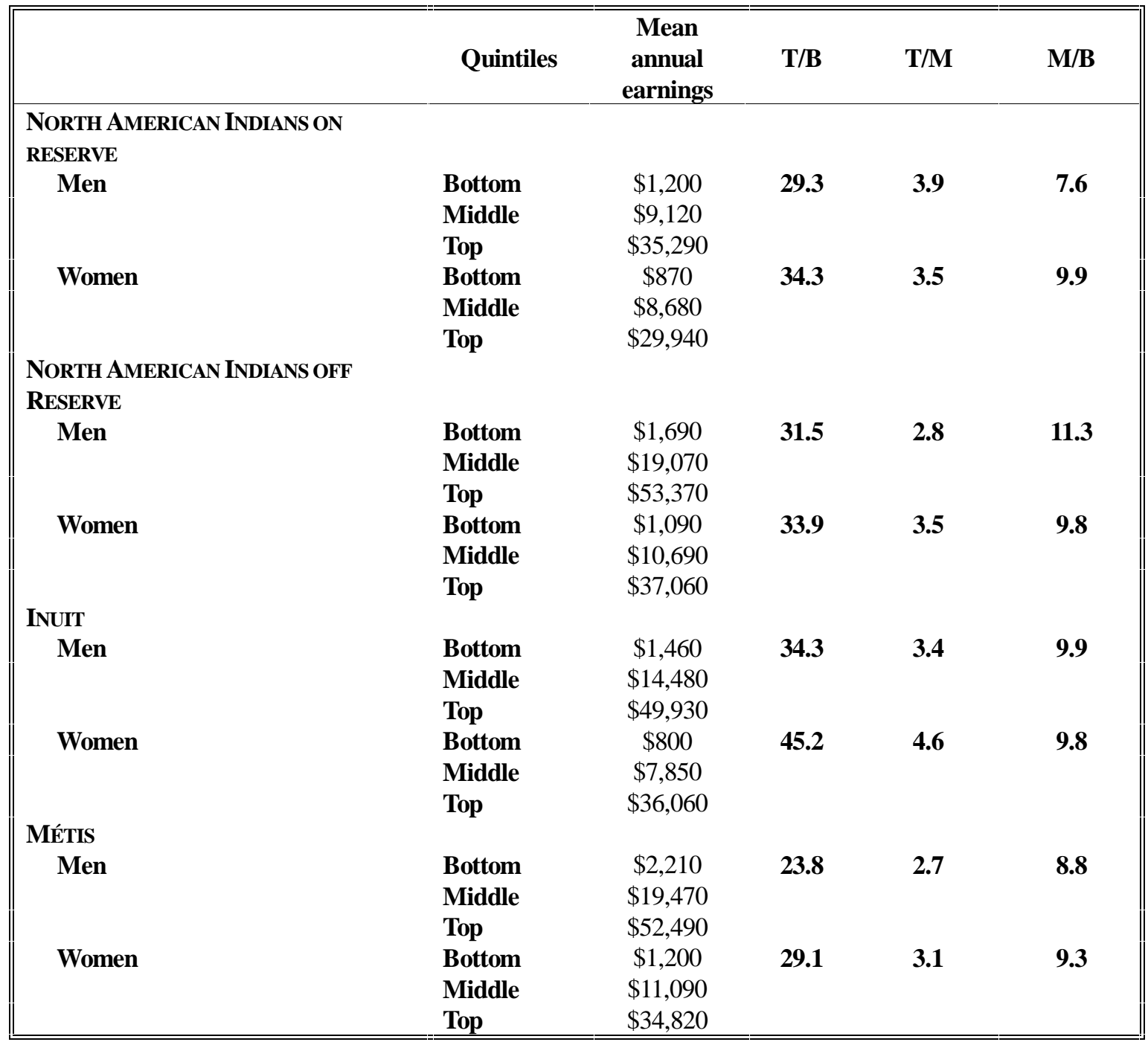

Source: Statistics Canada, Aboriginal Peoples Survey, 1991 (adults file) 